\title{
Engaging Secondary STEM Teachers in Automotive Engineering and Alter- native Energy Research at a University Site
}

\section{Prof. Xia Wang, Oakland University}

Dr. Xia Wang is a professor in the department of Mechanical Engineering at Oakland University. Her research and teaching interests lie in the areas of fluid mechanics and heat transfer, with an emphasis on fuel cell and battery technology.

\section{Dr. Anica Gwenell Bowe, Oakland University}

Dr. Bowe is an Assistant Professor at Oakland University in Rochester Michigan. She earned a Ph.D. in Education Psychology with a focus in Quantitative Methods in Education. Her interests are in evaluation practices for school-based initiatives, instrument development, the psycho-social development of immigrant adolescents, and education evaluation within the Caribbean.

\section{Dr. Chris J Kobus, Oakland University}

Director of Outreach, Recruitment and Retention, and Associate Professor School of Engineering and Computer Science (SECS) Director, HTech Jobs of the Future Program Director of Engineering and Energy Education OU Inc Clean Energy Research Center (CERC) OU Center for Excellence in Teaching and Learning (CETL) Faculty Fellow Oakland University Rochester, MI 48309 


\title{
Engaging Secondary STEM Teachers in Automotive Engineering and Alternative Energy Research at a University Site
}

\begin{abstract}
The department of mechanical Engineering at Oakland University was awarded by the National Science Foundation (NSF) a three year Research Experience for Teachers(RET) grant to support a group of secondary STEM teachers to conduct Automotive Engineering and Alternative Energy research at Oakland University. The program has run successfully for three consecutive summers between 2016 and 2018. The program aims to inspire K-12 STEM teaching and learning by engaging the secondary STEM teachers in the research project as well as exposing them to engineering education pedagogy. A total of 36 teachers from 12 different schools have taken part in the program. More than half of the participants were female teachers, and nearly half of the participants taught at urban schools with high percentage of students of color. The RET participants worked in teams with graduate students and faculty mentors on automotive engineering and alternative energy related projects, and participated in other activities such as research seminars, machine shop training, CAD workshop, and industrial sites visit. Another important element of the program is engineering related course module development. The RET participants took 16 hours course module development workshop during the course of the program, and each participant was expected to design and develop a course module in the summer and implement it in the classroom in the following academic year. Over the 3 years of the program, the RET participants created 29 engineering modules to implement inside their classrooms. The purpose of this paper is to share the experience of organizing and running such a research and teaching program for the teachers and to report the program organization, outcomes and some assessments results.
\end{abstract}

\section{Introduction}

The science and engineering workforces in the US are aging rapidly in general [1] and there is a steady decline in the number of engineers 35 and younger [2]. This is expected to become more severe in the automotive industry where many baby boomers are reaching retirement age, while the number of educated STEM graduates in Michigan has been declining [3]. It is imperative that this talent gap be bridged and that we work on providing a steady supply of engineers to our country. Students in K-12 schools are the engineers of the future, and inspiring and helping their teachers attain research experiences and the knowhow to bring that experience into their classrooms results, in turn, better learning for the students. The RET program at Oakland University (OU) [4] aimed to build a dynamic program centered on automotive engineering and alternative energy (AEAE) research that excites and educates middle school and high school STEM teachers, and thereby affects the lives of their students, and inspire their interest in STEM fields. We aim to bring the excitement and knowledge developed in engineering research from the research lab into the classroom so that teachers can inspire their students to envision engineering as an attractive and important academic and career opportunity, and to fill the desperately needed talent gap in the high tech economy of today and tomorrow.

This paper will briefly discuss the organization of this program including Application and Recruiting, Program Structure and Activities and Teacher Research Project. This paper will focus on the Program Assessment. Some lessons we learn while running the program will be also provided. 


\section{Recruitment and Application}

In order to advertise the program, flyers with information about the program and a link to the website were e-mailed to the superintendents of schools districts in metro-Detroit area in early January. A link to the program website was setup through the NSF RET page [4] and the following people were contacted: past AEAE RET teachers, past applicants, professors in school of Education, our outreach schools contacts. Over 60 applications were received from more than 10 different Schools districts across the metro Detroit area between 2016 and 2018. Of all the recruiting efforts used, the most effective were the messages sent to the principal of each school as well as word of mouth from past RET teachers.

The applications include a background questionnaire, a statement of interest, information regarding engineering/science background and courses taught or developed, and two letters of recommendation. PI and co-PI and some faculty members from the School of Education meet in the end of March and select the applicants by carefully examining their resumes, letters of recommendation, the personal statement, and their mentoring experience and interest.

In the summers of 2016, 2017 and 2018, a total of 36 STEM teachers from 12 different schools in Metro Detroit area. Table 1 shows the profiles of teachers between 2016-2018.

Table 1: Profiles of RET-OU participants between 2016-2018

\begin{tabular}{|c|c|c|c|c|}
\hline & & 2016 & 2017 & 2018 \\
\hline \multirow{4}{*}{ 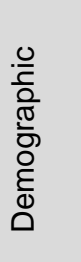 } & No. of Teachers & 11 & 11 & 14 \\
\hline & $\%$ Female & $54.5 \%$ & $36.3 \%$ & $71.4 \%$ \\
\hline & $\%$ Returning & - & $27.3 \%$ & $50 \%$ \\
\hline & $\%$ Caucasian/African American & $100 \% / 0 \%$ & $91 \% / 0 \%$ & $79 \% / 14 \%$ \\
\hline \multirow[b]{2}{*}{ 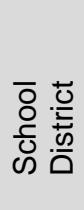 } & $\%$ from Minority Serving Districts & $54.5 \%$ & $45.4 \%$ & $50 \%$ \\
\hline & School Districts* & $\begin{array}{l}a(2), b(1), c(2 \\
), d(1), e(1), f( \\
1), j(1), k(2)\end{array}$ & $\begin{array}{l}a(2), b(2), c(1), f( \\
2), g(1), h(1), i(1)\end{array}$ & $\begin{array}{l}a(1), b(3), c(3), g( \\
1) h(3), l(1), j(1), l( \\
1)\end{array}$ \\
\hline \multirow{3}{*}{ 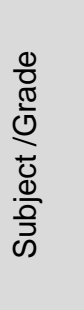 } & $\begin{array}{l}\% \text { Math } \\
\% \text { Science } \\
\% \text { STEM Teacher }\end{array}$ & $\begin{array}{l}27.3 \% \\
45.4 \% \\
27.3 \%\end{array}$ & $\begin{array}{l}18.2 \% \\
63.6 \% \\
18.2 \%\end{array}$ & $\begin{array}{l}42.9 \% \\
42.9 \% \\
14.2 \%\end{array}$ \\
\hline & \% Middle School /\% High School & $18 \% / 82 \%$ & $27 \% / 73 \%$ & $28 \% / 72 \%$ \\
\hline & $\begin{array}{l}\% \text { Pre-service teachers } \\
\%(1-3) \text { year Teachers }\end{array}$ & $9 \%$ & $\begin{array}{l}9 \% \\
9 \%\end{array}$ & $14.2 \%$ \\
\hline
\end{tabular}

*Note: We recruited teachers from 12 different schools in the metro Detroit area including (a) Avondale Academy (64\% African American, 12\% Hispanic/Latino, and 22\% white), (b) Oak Park High School (97\% African American, 3\% White), (c) Arts and Technology Academy of Pontiac (72\% African American, 25\% Hispanic/Latino, and 3\% white), (d) Lake Orion, (e) Utica, (f) Birmingham, (g) Stony Creek, (h) Grosse Pointe, (i) Fraser, (j) Detroit Catholic school and (k) Southfield HS(98\% African American, 1\% Hispanic, and 2\% white), (l) Van Hoosen. 
Among the 36 teachers, more than 50\% were female. In summer 2018, we successfully recruited two African American teachers. Nearly half of the teachers were from the minority serving schools. For example, the Oak Park High School has 97\% African American students which live in the city of Detroit; the Pontiac school district has 72\% African-American and 25\% Hispanic students in the Greater Detroit area; the Avondale Academy has 64\% African American, and $12 \%$ Hispanic/Latino students. We have recruited six teachers from the Oak Park High School, six teachers from Pontiac and five teachers from the Avondale Academy. The teacher's teaching subject varies from Math, Science (Biology, Physics and Chemistry) and STEM. Nearly 80\% of the teachers are high school teachers, and $20 \%$ are middle school teachers. We have recruited two pre-service teachers in summer 2016 and summer 2017, two first year teachers in summer 2017 and summer 2018. Nearly a third of teachers have 5 10 years of teaching experience, and the rest of them have over 10 years of teaching experiences.

\section{Program Structure and Activities}

The program ran for six weeks during the summer. Teachers received a $\$ 6,000$ (in-service) or $\$ 4,200$ (pre-service) stipend as well as a small meal allowance. Each teacher has received up to $\$ 2000$ for the supplies in their lesson plans. Teachers worked in teams on their respective research projects. The teams worked closely with the engineering faculty members supervising their projects and graduate students. In addition a number of group activities were also organized. These activities include industrial sites visit, research seminars and some professional training such as CAD, machine shop and 3D printing. Besides research activities in the research lab, the faculty member from the School of Education and Human Resources offered a projectbased learning workshop each Thursday. This aims to help the RET teachers to transform what they have learned from the research project to the knowledge in the classroom. They also learned the method of course module design. With the help of workshop, most of RET teachers have submitted a course module (or draft) by the end of summer. In the final day of the program, each group gave an oral presentation for the research project they have been working on. They also presented the course module plan derived from the research experience during the summer. During the lunch time, the group made the poster presentation. OU professors, students, teachers, industry mentors, and administrators from high and middle schools attended the presentation.

Table 2 are some highlights of the schedule of group activities during the summer of 2018 (Note that not all activities are listed in the table; in particular, activities/tours that were specific to individual project teams are not listed in this table).

\section{Teacher Research Projects}

Eight faculty members from the school of engineering volunteered to supervise teacher projects in the summers of 2016-2018. Each engineering faculty member gave an overview of his/her project on the second day of the program and gave teachers the opportunity to tour the lab facilities and ask questions before being asked to rank the projects by order of preference on the third day. Project assignment involved taking the teachers’ preferences in mind, as well as trying to pair up appropriate skills and backgrounds to each project. Most teachers received their first or second choice and were generally pleased with the project assignment process. A total of 15 projects have been conducted over the three summers. Some of the projects included: 1) Evaluating the Performance of Lithium Ion Batteries Under Cold Environment, 2) Construction and Improvement of a Fly Eye Vision Sensor, 3) Friction of Steel and Brass with Graphene 
Nanolubricant, 4) Thermal and Structural Properties of Lightweight Concrete, and 5) Digital Image Correlation in the Determination of Failure Modes of Industrial Vacuum Cups. The complete list of projects is posted on our website [4]. These research projects have so far resulted in three peer-reviewed conference technical papers involving teachers [5-7], and two conference papers and poster presentations by faculty about the RET program [8-9].

Table 2 - Highlights of RET Group Activities by Week Number, Summer 2018

\begin{tabular}{|l|l|}
\hline 1 & - Welcome and Orientation; Introduction of participating faculty and mentors; \\
& Introduction of participating students; Description of RET program, activities, \\
expectations; Open discussion on research; Lunch with faculty and student mentors; \\
Paperwork; campus tour \\
- Project Descriptions: Overview of each project and research method; Lab tours; Library \\
orientation and online resources \\
- Project Selection: Open discussion with faculty on projects; Survey on project \\
preference; Project assignment \\
• Introduction to using Machine shop and 3D Printers and lab safety. \\
• Workshop: Best practice in STEM
\end{tabular}

\section{Program Assessment}

The five major goals we set for the RET-OU project were to achieve Research Innovation, Teacher Engagement, Industry Involvement, Collaborative STEM Partnerships, Classroom Connections [9]. The ultimate goal of this project was to impact K-12 STEM teaching and learning, particularly for underrepresented groups of students. We measured the achievement of three of the major goals (Research innovation, industry involvement, and collaborative STEM partnerships) via the implementation of the processes of the summer research. We measured Teacher Engagement, Classroom Connections and the ultimate goal, that is, impacting K-12 STEM teaching and learning, particularly for underrepresented groups of students by how well we achieved our intermediate and final outcomes as denoted in the logic model of our evaluation plan. The paragraphs below benchmark our successes in meeting these goals.

Research innovation, industry involvement, and collaborative STEM partnerships: The RET teachers worked in collaborative teams each summer consisting of 2-3 teacher participants, one 
STEM faculty, one or two graduate students, and on occasion, undergraduate and high school students. Thus, teams represented a collaborative STEM partnership involving 6th-12th grade teachers, OU faculty, and OU students. Each team worked on cutting edge research in engineering. All together, there were 15 projects over three years. The findings of their research were important to the work of certain AEAE fields, thus benchmarking research innovation. Finally, each summer, RET participants went on field trips to two to three industrial engineering sites with connections to at least five of their projects. In total, there were five industry sites visited. We also invited an industrial speaker to present for our teachers. This then benchmarks industry involvement in the RET program.

Teacher Engagement, Classroom Connections and Impacting K-12 STEM teaching and learning: The intermediate and final outcomes all measure aspects of teacher engagement and classroom connections which ultimately inform on impacting K-12 STEM teaching and learning, particularly for underrepresented groups of students. The intermediate outcomes were for RET-OU participants to 1) teach more engineering content knowledge inside their classrooms 2) increase their implementation of an inquiry approach in their classrooms 3) have an increase in self-efficacy in STEM teaching and 4) encourage more 6-12th grade students into STEM fields. The final outcomes were to 1) improve underrepresented students' knowledge of and motivation to enter AEAE \& STEM careers 2) have more underrepresented teachers and students participating in STEM research 3) develop engineering content modules for the secondary classroom and 4) develop a website for the program. We provide evidence of how each of these outcomes were met in the following paragraphs.

1. More underrepresented teachers and students participating in STEM research. The RETOU program recruited 36 participants for the three summers. The demographics of these participants are highlighted in Table 1. Note that a number of these teachers taught at urban schools with high percentages of students of color (minority school districts). The table shows that by year three, the RET-OU program was successful in recruiting underrepresented teacher participants to engage in STEM research.

2. More engineering content taught in 6th-12th grade classrooms. The ultimate goal of this RET program is to enhance students' interest in STEM fields by infusing engineering concepts to the classroom. Over the 3 years of the program, the RET participants created 29 engineering modules to implement inside their classrooms. These course modules are mainly derived based on their research experience, with engineering component such as design with constraint considered. Many of Course modules are very high quality, and is in the process for publishing in teaching engineering [10]. A sample list of course modules is shown in Table 3, which reflects different school districts, different STEM subjects at both middle and high school levels. A complete list of course modules is posted on the website [4]. Note that these modules all made use of the inquiry approach to teaching to some extent. Further, many of these modules were implemented inside classrooms as observed by OU faculty visiting the sites. Thus, we also make the claim that this allowed more underrepresented students (that is those attending minority school districts) to participate in STEM research. In short, intermediate goals 1, 2 and final goals $1 \& 3$ were met. 
Table 3: Names of Selective $6^{\text {th }}-12^{\text {th }}$ grade Modules created by RET-OU participants

\begin{tabular}{|c|c|c|c|}
\hline No. & Course Module & Corresponding Research Project & $\begin{array}{l}\text { Subject/ } \\
\text { Grade } \\
\text { Level/School }\end{array}$ \\
\hline 1. & $\begin{array}{l}\text { Understanding } \\
\text { Electrical Impulses of } \\
\text { the Heart }\end{array}$ & $\begin{array}{l}\text { Construction and Improvement of a Fly Eye } \\
\text { Vision Sensor }\end{array}$ & $\begin{array}{l}\text { Biology-H } \\
\text { (Pontiac) }\end{array}$ \\
\hline 2. & $\begin{array}{l}\text { Atwood's Machines } \\
\text { and the Effects of } \\
\text { Friction Header }\end{array}$ & $\begin{array}{l}\text { Friction of Steel and Aluminum with } \\
\text { Graphene Nanolubricant }\end{array}$ & $\begin{array}{l}\text { Physics-H } \\
\text { (Detroit) }\end{array}$ \\
\hline 3. & $\begin{array}{l}\text { Forces and Tensile } \\
\text { Tests in Creating a } \\
\text { Hammock }\end{array}$ & $\begin{array}{l}\text { Determination of Material Properties of } \\
\text { Advanced High Strength Steel (AHSS)by } \\
\text { Advanced Optical Method }\end{array}$ & $\begin{array}{l}\text { Physics-M } \\
\text { (Avondale) }\end{array}$ \\
\hline 4. & $\begin{array}{l}\text { Net-Zero Greenhouse } \\
\text { Design and } \\
\text { Automation }\end{array}$ & Photovoltaic Integrated Greenhouse & $\begin{array}{l}\text { STEM-M } \\
\text { (Birmingham) }\end{array}$ \\
\hline 5. & $\begin{array}{l}\text { Engine Oil Analysis } \\
\text { Module }\end{array}$ & $\begin{array}{l}\text { Effects of Fuel-Dilution and Thermal } \\
\text { Cycling on Engine Oil Composition and } \\
\text { Tribological Properties }\end{array}$ & $\begin{array}{l}\text { Math-H } \\
\text { (Oak Park) }\end{array}$ \\
\hline 6 & $\begin{array}{l}\text { The Dog House } \\
\text { Challenge }\end{array}$ & $\begin{array}{l}\text { Evaluating the performance of Lithium ion } \\
\text { batteries under cold environment }\end{array}$ & $\begin{array}{l}\text { Chemistry-H } \\
\text { (Grosse } \\
\text { Pointe) }\end{array}$ \\
\hline
\end{tabular}

3. Increase in RET-OU participant self-efficacy to teach engineering. Participants completed pre $(n=33)$ and post surveys $(n=30)$ asking about their self-efficacy to teach engineering in a secondary school setting. Surveys were given on the first day of the summer program and again on the final day of the program. The survey had nine items measuring teacher beliefs about their pedagogical skills to teach engineering. The survey asked teachers to indicate their level of agreement on a six point scale (Strongly Disagree... Strongly Agree) with each item. Examples of items were: I can discuss how given criteria affect the outcome of an engineering design project, I can assess my students' engineering design products, I can craft good questions about engineering for my students and I can employ engineering activities in my classroom effectively [11-12]. Inferential statistics using independent samples $t$-test demonstrate that the summer research significantly improved the participants self-efficacies to teach engineering $(t(61)=3.91$, $p<.001$, CI $_{95}[4.09,12.67]$, Cohen's $\left.d=.99\right)$. We are pleased to report that the estimate for Cohen's d infers a large effect size [13]. (Note that independent samples $t$-test and not paired samples $t$-test were used because participants responded anonymously to the surveys, thus we could not track individual growth over time). Descriptive and inferential statistics demonstrate that the program was effective in increasing teacher self-efficacy to teach engineering in 6th-12th grade classrooms. Descriptive summaries of some key questions are in Table 4 and inferential statistics are reported immediately afterwards. (The reader should note that independent samples $t$-test and not paired samples $t$-test were used because participants responded anonymously to the surveys, thus we could not track individual growth over time). 
Data from the focus groups led by the program evaluator demonstrate that teachers thought that the summer program increased their understanding of how to implement evidence-based practice in their teaching; gave them a better understanding of an interdisciplinary approach to engineering; and increased their self-efficacies to engage in engineering research. For example, teachers made the following comments: "My ideas about research have developed in a real world, rich experience." "It stretched my thinking about engineering and gave me a real world experience to think about all year as I teach next year- and as I revise my teaching practice throughout the end of my career". Perhaps though the most consistent sentiment expressed by the teachers about engaging in research is that research takes patience.

Table 4: Teachers reported self-efficacies in teaching engineering pre-post summer program.

\begin{tabular}{|l|l|l|l|l|l|l|l|}
\hline I can & & St D & $\begin{array}{l}\text { M } \\
\text { D }\end{array}$ & Sl D & Sl A & M A & St A \\
\hline $\begin{array}{l}\text { Discuss how given criteria affect } \\
\text { the outcome of an engineering } \\
\text { design project. }\end{array}$ & PRE, N=33 & $15 \%$ & $9 \%$ & $6 \%$ & $27 \%$ & $33 \%$ & $9 \%$ \\
\cline { 2 - 8 } & POST, & $3 \%$ & & & $13 \%$ & $13 \%$ & $45 \%$ \\
\hline $\begin{array}{l}\text { Craft good questions about } \\
\text { engineering for my students. }\end{array}$ & PRE, N=33 & $9 \%$ & $9 \%$ & $9 \%$ & $36 \%$ & $21 \%$ & $15 \%$ \\
\cline { 2 - 8 } & $\begin{array}{l}\text { POST, } \\
\text { N=30 }\end{array}$ & $3 \%$ & & & $7 \%$ & $57 \%$ & $33 \%$ \\
\hline $\begin{array}{l}\text { Employ engineering activities in } \\
\text { my classroom effectively. }\end{array}$ & PRE, N=33 & $9 \%$ & $9 \%$ & $9 \%$ & $36 \%$ & $30 \%$ & $6 \%$ \\
\cline { 2 - 8 } & $\begin{array}{l}\text { POST, } \\
\mathrm{N}=30\end{array}$ & & $3 \%$ & & $17 \%$ & $43 \%$ & $37 \%$ \\
\hline $\begin{array}{l}\text { Guide my students' solution } \\
\text { development with the engineering } \\
\text { design process. }\end{array}$ & \begin{tabular}{l} 
PRE, N=33 \\
\cline { 2 - 8 }
\end{tabular} & $6 \%$ & $9 \%$ & $15 \%$ & $27 \%$ & $30 \%$ & $12 \%$ \\
\hline
\end{tabular}

Key: $\mathrm{St}=$ strongly, $\mathrm{Sl}=$ slightly, $\mathrm{M}=$ moderately, $\mathrm{D}=$ disagree, $\mathrm{A}=$ agree

\section{More underrepresented students increasingly more motivated to learn STEM content} During year one of the program, a focus group was conducted with secondary students taking an engineering course at an urban school within the Detroit metro area. This school had a predominately African American student body. Findings revealed that these students were able to engage first hand in engineering design throughout the school year. During the focus group students expressed high motivation in learning engineering content because they saw it as useful and applicable to daily lives which aligns with final outcome 1. Examples of students' comments include: African American male student: "well not in school, it's like a heater that you put in a room. So one day I came home, my heater stopped working, so instead of buying a new one I took it apart see what's like wrong with it, then fixed it and the next thing our door bell stopped working. I fixed the doorbell. It's honestly from the stuff that we learn in class and go home you go home, you start fixing things". While the conversation did not get into their interest in STEM careers, 
these students consistently reported seeing engineering as more applicable to their lives versus science content areas.

\section{Conclusions and Lesson Learned}

Taken together, the RET-OU program was successfully achieved its ultimate goal of impacting K12 STEM teaching and learning, particularly for underrepresented groups of students. We have increased the course module dramatically from six out of eleven in the first summer, to nine out of eleven in the second summer, and to fourteen out of fourteen in the last summer. We have done two things: we hold a \$1000 payment until the end of August to encourage the RET teachers to submit the lesson plan in the second and third summers. The other, is also the most important, is to provide more instructional support to teachers. In the last year of the program, we required Teaching Engineering template as a course module template. Each Wednesday and Thursday afternoons, the teachers work as a group with the Faculty advisor from the School of Education to brainstorm and design their course module. This helps teacher significantly to form the idea of transforming their learning experience to the classroom.

In short, the RET-OU program engaged STEM middle/high school teachers in cutting edge AEAE research, increased teachers' self- efficacies to teach engineering in 6th-12th grade classrooms, and resulted in more engineering taught in Michigan's schools, particularly in schools with higher percentages of underrepresented students. It also helped bridge the gap between the teaching and learning that takes place in secondary schools and the teaching \& learning that takes place OU as RET-OU faculty were able to make 12 site visits to these schools over the course of two years. This is especially meaningful because it allowed RET-OU faculty to a) have access to schools that they usually wouldn't have access to b) observe students' thinking about STEM and c) learn how teachers make engineering content come alive inside 6th12th grade classrooms. We are still in touch with our previous RET participants, and we will continue to visit their classrooms and to look for ways to improve the program and its outcomes.

\section{Acknowledgement}

The authors gratefully acknowledge the support of the National Science Foundation RET program through NSF Award \# 1542333. Special thanks go to all of the teachers who have taken part in the program.

\section{References}

1. Blau, D. and Weinberg, B.A., Why the US Sicence and engineering workforce is aging rapidly, PNAS, April, 2017, 114(15) 3879-3884.

2. 2017 Machine Design Anuual Salary and Career Report.

3. https://www.bridgemi.com/special-report/michigan-business-climate-improves-educatedworkforce-shrinking, retrieved on Sep 10, 2018.

4. http://ret.secs.oakland.edu/

5. C.J. Kobus, M. Huyssen, R. Piper, J.D. Schall, X. Wang, L. Guessous, "Thermal Resistance and Compressive Strength of Polystyrene-Seeded Concrete for Better Insulative Value”, accepted for presentation and publication at the ASME International Mechanical Engineering Congress and Exposition (IMECE), Pittsburgh, PA, Nov 9-15, 2018.

6. Agrawal, S., Dean, B., Grimm, W., Carpenter, K., and Motzny, M., Removal of Signal Artifacts from Biomimetic Vision Sensor Based on the Common Housefly,2017 IEEE 
International Symposium on Medical Measurements and Applications (MeMeA), May 7$10,2017$.

7. Xu, Z, Xu, M, Wang, X, Zhao, P. and Kim S., Conductive Heating of Li-Ion Batteries at Low Temperatures, ASME 2018 International Mechanical Engineering Congress and Exposition, Nov 9-15, 2018, Pittsburgh, PA, USA. Paper \# IMECE2018-88235.

8. C.J. Kobus and X. Wang, "Research Experience for Teachers - Similarities with REU Experience" accepted for presentation at the ASME International Mechanical Engineering Congress and Exposition (IMECE), Pittsburgh, PA, Nov 9-15, 2018.

9. Wang, X., Bowe A., Dean, B., Kobus, C, and Olson, M., First Year Experience of Running the Research Experience for Teachers in Alternative Energy and Automotive Engineering Program, $124^{\text {th }}$ Annual Conference and Exposition of American Society for Engineering Education, June 25-28, 2017, Columbus, Ohio, Paper \#17911.

10. https://www.teachengineering.org/

11. Yoon Yoon, S., Evans, M. G., \& Strobel, J. (2014). Validation of the Teaching Engineering Self-Efficacy Scale for K-12 Teachers: A Structural Equation Modeling Approach. Journal of Engineering Education, 103(3), 463-485.

12. Yoon, S. Y., Evans, M. G., \& Strobel, J. (2012, June). Development of the teaching engineering self-efficacy scale (TESS) for k-12 teachers. In 2012 ASEE Annual Conference \& Exposition (pp. 25-466).

13. Cohen, J. (1992). A power primer. Psychological bulletin, 112(1), 155. 